\title{
Prevalence of addictive internet use and its correlates among urban school students in Tamilnadu, South India - a cross-sectional study
}

\author{
Daya A P. ${ }^{1}$, Krishnaleela G. ${ }^{2 *}$
}

DOI: https://doi.org/10.17511/ijphr.2018.i2.02

\footnotetext{
${ }^{1}$ Praveena Daya A, Assistant Professor, Department of Community Medicine, Tirunelveli Medical College, Tirunelveli, Tamil Nadu, India.

2* Krishnaleela G, Associate Professor, Department of Community Medicine, Thoothukudi Medical College, Thoothukudi, Tamil Nadu, India.
}

Background: Use of Internet has drastically increased in the last decades. Despite of the advantages, use of it can lead to addictive behaviours that can affect various domains of a person's life like physical, social, mental and financial wellbeing. Materials and Methods: A cross-sectional study was conducted to assess the prevalence of Internet use and its correlates among 150 urban school students in 13-15 years age group in a selected school in Tirunelveli district, Tamilnadu, South India. Study was conducted using apredesigned, pretested questionnaire part of the questions were retrieved from Young's 20 item Internet Addiction Test. Results: Among the 150 study participants, $53(35.4 \%)$ are not addicted to use of internet, 63 (42\%) are in mild addiction level, $29(19.3 \%)$ are in moderate addiction level and 5(3.3\%) comes under severe addiction level, $43.4 \%$ were using internet for social networking and with regard to duration of use of internet, $17 \%$ were using internet for duration of 1-2 hours a day and $6 \%$ use it for more than 2 hours a day. Conclusion: The current study shows a higher level of internet use and addiction to it among students. Need to enhance the awareness regarding the consequences of these technologies to students.

Keywords: Internet, Addiction, School students, Urban schools

Corresponding Author

Krishnaleela G, Associate Professor, Department of Community Medicine, Thoothukudi Medical College, Thoothukudi, Tamil Nadu, India.

Email: drdayamd@gmail.com
How to Cite this Article

To Browse

Daya AP, Krishnaleela G. Prevalence of addictive internet use and its correlates among urban school students in Tamilnadu, South India - a crosssectional study. Public Health Rev Int J Public Health Res. 2018;5(2):60-64.

Available From

https://publichealth.medresearch.in/index.php/ijphr/

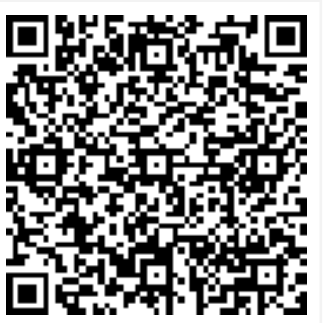
article/view/83
Manuscript Received 2018-04-08

Conflict of Interest No

Review Round 1
2018-04-18
Funding
Nil

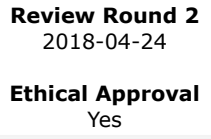

Review Round 3

Accepted 2018-04-27

Plagiarism $\mathbf{X}$-checker $5 \%$

Note

(c) 2018 by Praveena Daya A, Krishnaleela G and Published by Siddharth Health Research and Social Welfare Society. This is an Open Access article licensed under a Creative Commons Attribution 4.0 International License https://creativecommons.org/licenses/by/4.0/ unported [CC BY 4.0]. 


\section{Introduction}

Use of computers, Internet, smartphones and other similar electronic devices has drastically increased in the last decades in most of the developed and developing countries of the world. It helps people to connect withthe world much easier than before and it promotes many public health activities in aspects of providing information to the public, faciliting prosocial activites and few other factors. But the excessive use of these electronic devices creates a concern.

Use of these devices vary widely and it can lead to addictive behaviours characterized by uncontrollable impulse to engage repeatedly in using these devices for the purpose of video gaming, retrieving pornographic materials, gambling, social media and other purposes despite of the hazards caused by them to various domains of a person's life like physical, social, mental and financial wellbeing [1].

This may emerge as a major public health problem globally and warrants immediate consideration. Internet addiction has been broadly defined as use of Internet which interfere with a person's health and leads tosocial, psychological, school and/or work difficulties [2]. It is also revealed that $88.3 \%$ of people with internet addiction have two other cooccurring conditions [3].

Few studies have reported internet addiction as an addictive behaviour or as an impulse-control disorder $[4,5]$. Addiction to internet has also been mentioned asa Behavioural Addiction as it results in a persistent behavior among the users despite being aware of its adverse effects.

Block suggested four diagnostic criteria for internet addiction as [1] excessive use of internet associated with neglecting basic drives or loss of time sense [2] withdrawal symptoms like feelings of anger, depression and tension when Internet becomes inaccessible; [3] tolerance, includes need for better computer equipments, more hours of use, more software; [4] adverse consequences (e.g., lateness for early morning appointments, neglect of occupational duties, sleep deprivation, marital difficulties) [6].

Worldwide various studies have assessed the addictive internet use and its health hazards among different population, but there is paucity of evidence in the current geographic region [7-9].
So the current study assessed the prevalence of Internet use and its correlates among urban school students in Tirunelveli district, Tamilnadu, South India

\section{Materials and methods}

Objective: To assess the prevalence of Internet use and its correlates among urban school students in Tirunelveli district, Tamilnadu, South India.

Study type: School based Cross-sectional study

Sample size: Study was conducted among 150 urban school going students in 13-15 years age group in a selected school in Tirunelveli district, Tamilnadu, South India.

Study tool: Study was conducted using a predesigned, pretested questionnaire. The first part of the questionnaire was framed to retrieve the socio-demographic informations of the participants like age, gender, education status of their parents, occupation status of their parents, income of parents and socio-economic status.

The second part of the questionnaire was retrieved from Young's 20 item Internet Addiction Test [10]. It is a 20 item valid, reliable questionnaire developed by Dr. Kimberly Young for measuring various levels of internet addiction like mild, moderate and severe levels of addiction.

This 20 item questionnaire is answered on a 5 point Likert scale which assess the levels of addictive internet use and its effects on person' social life, sleep, academic performance, interpersonal relationships, emotions etc.

The questions are answered in a severity rating of 1 (rarely) to 5 (always) and the total score is calculated by adding all the individual item scores. Higher scores indicate greater level of internet addiction.

\section{Interpretation of scores}

20 - 49 points: Indicates the person is an average internet user who may use internet for a bit too long at some times, but has control on its use.

50 - 79 points: Indicates the person is experiencing frequent oroccasional or problems due to Internet use.

80 - 100 points: Indicates the person is experiencing significant issues because of internet use addiction. 
The person is in need to evaluate and address the problems because of the impacts of Internet use on their life.

Procedure: The current study was conducted in an urban school selected based on convenient sampling. The objectives of the study were explained and permission was obtained from the school officials. Parents were informed regarding the objectives of the study and written consent was obtained from them.

Data was collected from the students after explaining the purpose of the study and after obtaining their willingness for participation in the study.Contents of the questionnaire were explained and data was collected using a self-administered questionnaire and privacy was maintained during data collection.

Data entry and analysis: Data was entered in Microsoft excel sheet 2010 and was analyzed using SPSS software version 21. Descriptive analysis was done and results were expressed in prevalence percentages.

\section{Results}

Age, gender distribution and social class of study participants were as follows (Table 1 )

Table-1: Socio-demographic characteristics of study participants $(\mathbf{n}=\mathbf{1 5 0})$

\begin{tabular}{|l|l|l|}
\hline \multicolumn{1}{|c|}{ Age in years } & \multicolumn{1}{c|}{ Frequency } & \multicolumn{1}{c|}{ Percent } \\
\hline 13 & 44 & $29 \%$ \\
\hline 14 & 96 & $64 \%$ \\
\hline 15 & 10 & $7 \%$ \\
\hline Total & 150 & $100 \%$ \\
\hline Gender & 70 & $47 \%$ \\
\hline Males & 80 & $53 \%$ \\
\hline Females & 150 & $100 \%$ \\
\hline Total & \multicolumn{2}{|l}{} \\
\hline Socioeconomic status & 78 & $52 \%$ \\
\hline Upper & 71 & $47.3 \%$ \\
\hline Upper middle & 1 & $.7 \%$ \\
\hline Lower middle & \multicolumn{2}{|l}{} \\
\hline
\end{tabular}

Among the 150 study participants, majority (64\%) are in 14 years and $52 \%$ belong to upper social class as per Modified Kuppuswamy Socio-economic scale.

Levels of internet addiction among students were shown in Figure. 1

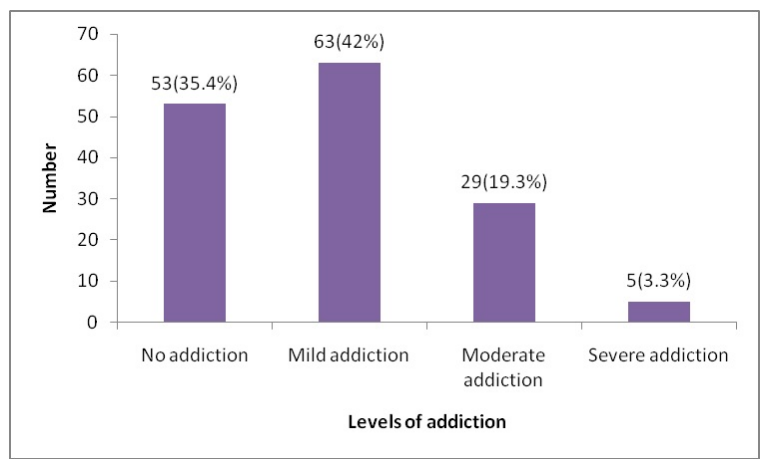

Fig-1: Levels of Addiction of internet use among study participants $(n=150)$

Amongthe 150 study participants, 53 (35.4\%) are not addicted to use of internet, $63(42 \%)$ are in mild addiction level, 29(19.3\%) are categorized under moderate addiction level and 5(3.3\%) comes under severe addiction level. Purpose of use of internet among study participants were shown in table. 2

Table-2: Purpose of use of internet among the study participants $(\mathbf{n = 1 5 0})$.

\begin{tabular}{|l|l|l|}
\hline \multicolumn{1}{|c|}{ Purpose of use of internet } & Number & Percentage \\
\hline Social networking & 65 & 43.4 \\
\hline Watching movies \&Listening to music & 41 & 27.3 \\
\hline Academic purpose & 29 & 19.3 \\
\hline Playing games & 15 & 10 \\
\hline Duration of use of internet & 53 & 35 \\
\hline Rarely & \multicolumn{2}{|l}{} \\
\hline Used only during week ends & 33 & 22 \\
\hline$<30$ minutes a day & 30 & 20 \\
\hline 1 hour - 2 hours a day & 25 & 17 \\
\hline$>2$ hours a day & 9 & 6 \\
\hline
\end{tabular}

Among the 150 study participants, 43.4\% were using internet for the purpose of communicating with others through social media followed by $27.3 \%$ for watching movies and listening to music. With regard to duration of use of internet, $17 \%$ were using internet for duration of 1-2 hours a day and $6 \%$ use it for more than 2 hours a day. Addictive internet use based on gender were shown in table. 3

Table-3: Addictive internet use based on gender $(\mathbf{n = 1 5 0})$

\begin{tabular}{|c|c|c|c|c|c|}
\hline \multirow[t]{2}{*}{ Gender } & \multicolumn{4}{|c|}{ Levels of addiction } & \multirow[t]{2}{*}{ Total } \\
\hline & $\begin{array}{l}\text { No } \\
\text { addiction }\end{array}$ & $\begin{array}{l}\text { Mild } \\
\text { addiction }\end{array}$ & $\begin{array}{l}\text { Moderate } \\
\text { addiction }\end{array}$ & $\begin{array}{l}\text { Severe } \\
\text { addiction }\end{array}$ & \\
\hline Females & 26 & 33 & 9 & 2 & 70 \\
\hline Males & 27 & 30 & 20 & 3 & 80 \\
\hline Total & 53 & 63 & 29 & 5 & 150 \\
\hline
\end{tabular}


With regard to gender and internet addiction, moderate addiction is observed to be more among male students. But there is no statistical significance in difference of addictive internet use observed between males and females ( $p$ value $=0.66$ ).

\section{Discussion}

The current study done in school students has showed that among the 150 study participants, $63(42 \%)$ are in mild addiction level, 29(19.3\%) are categorized under moderate addiction level and $5(3.3 \%)$ comes under severe addiction level. Around $43.4 \%$ were using internet for social networking followed by $27.3 \%$ for watching movies and listening to music. Study by Olatokun WM et al [11] among 300 secondary level school students in Nigeria showed that 125 (47.9\%) of participants use Internet weekly, $23.8 \%$ use monthly, 47 participants use internet daily and $7.7 \%$ mentioned the use of internet fortnightly. This is comparable with the current study, in which $22 \%$ used internet during weekends and $43 \%$ were using daily. Study by Sharahi BY et al [12] among 340 students showed widespread use of internet among students inmany cases and there exists a significant relationship between internet dependence and reduced academic performance. It has reduced their leisure time, has affected their communication with others, related to aggressive tendencies, leads to social isolation. Study by Niemz $\mathrm{K}$ et al [13] among 371 British students with a Pathological Internet Use (PIU) scale, the General Health Questionnaire (GHQ-12) revealed that $18.3 \%$ of students were categorized as pathological Internet users, as their internet use was associated with their social, academic and interpersonal problems. Other results showed that pathological Internet users had lower self-esteem and were more socially disinhibited. However, there was no significant difference in GHQ scores. The current study showed significant issues because of internet use among $5(3.3 \%)$ students. Study by Keith J Anderson [14] among 1300 college students in US revealed an average use of internet of 100 minutes per day among study participants and $6 \%$ use internet for more than 400 minutes per day. This show a higher duration of internet use among the students when compared with the present study were $6 \%$ were using internet for more than 2 hours a day, $17 \%$ for $1-2$ hours a day and $35 \%$ were using it rarely. Study by Ronald Tarimo and George Kavishe [15] in Tanzania among 120 students showed $78(87.6 \%)$ of students were using Internet services for gaming and downloading music,
$73(82.0 \%)$ were using for academic purpose, 72 (80.9\%) used it for gaming, 55(61.8\%) using for entertainment, 51 (57.3\%) browse for visiting various websites, $50(56.2 \%)$ mentioned using it to read newspapers online and $44.9 \%$ for instant messaging. The current study shows a different pattern of internet use among students as $43.4 \%$ of them use it for social networking followed by $27.3 \%$ use for watching movies and listening to music, $19.3 \%$ were using it for academic purpose and $10 \%$ for playing games. Study by Xin M et al [16] among 6468 adolescents in China showed a $26.50 \%$ prevalence of Addictive internet use overall and $0.96 \%$ severe addiction. Addictive internet use was found to be more among males (30.6\%) than females $(21.2 \%)$. Internet was maximum used for social networking ( $94.73 \%$ ) followed by school work $(86.53 \%)$, entertainment $(82.44 \%)$, gaming in internet $(73.42 \%)$ and online shopping (33.67\%). The current study show a higher level of internet use among students (64.6\%) overall and 3.3\% were in severe addiction level in which the maximum use of internet was for social networking followed by entertainment purpose (watching movies and listening to music).

\section{Conclusion}

The current study done among urban school students to assess the prevalence of internet use has shown a higher level of internet use and addiction to it among them. Parents need to be educated regarding the consequences of these technologies to children.

Accessibility to these devices can be restricted to prevent them from getting addicted and health education sessions need to be organized regularly in schools to create awareness among the students regarding their consequences in various domains of life.

\section{Impact of current study}

The current study has created evidence regarding the level of addictive internet use in the current geographic region. This evidence can be used for policy making in educating teachers in identifying symptoms of addictive internet use among the students for preventing them from consequences.

\section{Contribution of authors}

Praveena Daya A: Involved in designing the study, data collection, data analysis, manuscript writing 
And review

Dr Krishnaleela G: Involved in designing the study, manuscript writing and review

\section{Reference}

01. Foundation for Promotion of Cancer Research National Cancer Research Centre, Tokyo, Japan. Public Health Implications of Excessive Use of the Internet, Computers, Smartphones and Similar Electronic Devices Meeting report. Geneva: World Health Organization. 2015;151p. [Crossref]

02. Spada MM. An overview of problematic internet use. Addict Behav. 2014 Jan;39(1)3-6.

doi:10.1016/j.addbeh.2013.09.007. Epub 2013 Oct 2 [Crossref]

03. Tzang RF, Chang $\mathrm{CH}$, Chang YC. Adolescent's psychotic-like symptoms associated with Internet addiction. Psychiatry Clin Neurosci. 2015 Jun;69(6)384.

doi: 10.1111/pcn.12243. Epub 2014 Nov 14 [Crossref]

04. Potenza MN. Should addictive disorders include non-substance-related conditions?. Addiction. 2006 Sep; 101; Suppl-1;142-51.

[Crossref]

05. Yau YHC, Crowley MJ, Mayes LC, Potenza MN. Are internet use and video-game playing addictive behaviors?- Biological, clinical and public health implications for youths and adults. Minerva Psichiatr. 2012 Sep;53(3)153-70. [Crossref]

06. Block JJ. Issues for DSM-V- internet addiction. Am J Psychiatry. 2008 Mar;165(3)306-7. doi: 10.1176/appi.ajp.2007.07101556 [Crossref]

07. Ni X, Yan H, Chen S, Liu Z. Factors influencing internet addiction in a sample of freshmen university students in China. Cyberpsychol Behav. 2009 Jun;12(3)327-30. doi: $10.1089 / \mathrm{cpb} .2008 .0321$ [Crossref]

08. Park SK, Kim JY, Cho CB. Prevalence of Internet addiction and correlations with family factors among South Korean adolescents. Adolescence. 2008 Winter;43(172)895-909.

[Crossref]
09. van den Eijnden RJ, Spijkerman R, Vermulst AA, van Rooij TJ, Engels RC. Compulsive internet use among adolescents- bidirectional parentchild relation-ships. J Abnorm Child Psychol. 2010 Jan;38(1)77-89.

doi: $10.1007 / \mathrm{s} 10802-009-9347-8 \quad$ [Crossref]

10. Internet addiction test [IAT] by $\mathrm{Dr}$ Kimberly Young.

Available from: [Article] [Crossref]

11. Olatokun WM. Internet access and usage by secondary school studentsin a Nigerian Municipality. SA Jnl Libs \& Info Sci. 2008;74(2)138-148.

[Crossref]

12. Sharahi BY, Ahmadi A, Goodarzi T, Beigi FH, Joukar J. A Survey of the Amount of Internet Usage among High School. Procedia - Social and Behavioral Sciences. 2014;114;610 - 616.

[Crossref]

13. Niemz K, Griffiths M, Banyard P. Prevalence of pathological Internet use among university students and correlations with self-esteem, the General Health Questionnaire (GHQ), and disinhibition. Cyberpsychol Behav. 2005 Dec;8(6)562-70.

[Crossref]

14. Anderson KJ. Internet use among college students- an exploratory study. J Am Coll Health. 2001 Jul;50(1)21-6.

[Crossref]

15. Tarimo R, Kavishe G. Internet access and usage by secondary school students in Morogoro Munic ipality, Tanzania. International Journal of Edu cation and Development using Information and Communication Technology. 2017;13(2)56-69. [Crossref]

16. Xin M, Xing J, Pengfei W, Houru L, Mengcheng W, Hong Z. Online activities, prevalence of Internet addiction and risk factors related to family and school among adolescents in China. Addictive Behaviors Reports. 2018;7;14-18. [Crossref] 